\title{
Wortmannin, a Radiation Sensitizer, Enhances the Radiosensitivity of WKAH Rat Cells but not That of LEC Rat Cells
}

\author{
Masanobu HAYASHI, Ai KAWANA, Daiji ENDOH and Toyo OKUI ${ }^{1)}$ \\ Department of Veterinary Radiology, Faculty of Veterinary Medicine, Rakuno Gakuen University, Ebetsu 069-8501 and ${ }^{1)}$ Hokkaido \\ Institute of Public Health, Sapporo 060-0819, Japan
}

(Received 25 August 1999/Accepted 1 October 1999)

ABSTRACT. No significant cytotoxic effect was observed in WKAH rat cells by the treatment of wortmannin, a radiation sensitizer, at concentrations lower than $30 \mu \mathrm{M}$ for $24 \mathrm{hr}$. The relative surviving fractions of LEC rat cells were slightly, but significantly, lower than those of WKAH rat cells at each concentration of wortmannin. When the wortmannin-treated WKAH rat cells were X-irradiated, the relative surviving fractions decreased in a wortmannin concentration-dependent manner. On the contrary, no significant difference was observed between the survival curves of untreated and wortmannin-treated LEC rat cells after X-irradiation.—KEY wORDS: DNA-dependent protein kinase, LEC rat cell, wortmannin.

J. Vet. Med. Sci. 62(2): 191-194, 2000

In humans, there are several syndromes such as ataxia telangiectasia (AT) with enhanced sensitivity to some chemical and physical genotoxic agents, including ionizing radiation [24]. These disorders are frequently associated with increased spontaneous and induced chromosome aberrations $[6,16,36]$, and a genetic predisposition to cancer $[12,27,32]$. The cells from AT patients are hypersensitve to ionizing radiation [33] and also characterized by radioresistant DNA synthesis [23]. AT cells show an abnormality of many or all of the transient cell cycle arrests that occur in normal cells following ionizing radiation $[2$, 17, 31]. Therefore, study of the enhanced sensitivity to ionizing radiation has brought light to some of the biological processes involved in DNA metabolism, such as repair, replication and cell cycle regulation.

LEC strain rats have been established at the Center for Experimental Plants and Animals, Hokkaido University [30]. Rats of this strain suffered from spontaneous fulminant hepatitis associated with severe jaundice at about 4 months of age. Other characteristics of LEC rats are a high incidence of spontaneous liver cancer in long-surviving individuals [35] and an increased sensitivity in vivo and in vitro to ionizing radiation $[7,8,10]$. We have reported that the hypersensitivity of LEC rats to whole-body irradiation is mainly controlled by a single autosomal recessive gene, xhs [9], and that LEC rat cells show high rates of $X$ irradiation-induced chromosome aberrations [22], and the abnormality of transient cell cycle arrest after X-irradiation [11]. Thus, LEC rat cells display characteristics similar to those of AT cells.

Although ionizing radiation produces a variety of lesions in DNA, double-strand breaks (DSBs) seem to be most responsible for radiation-induced cell death [18]. The important role of DSBs repair is suggested in the fixation of potentially lethal damage (PLD) [13]. It has been shown that DNA-dependent protein kinase (DNA-PK) plays an important role in the repair of DSBs [15, 20], but the role of
DNA-PK in the repair process of PLD remains unclear. Recently, we showed that the slow repair of PLD occurred in LEC rat cells, but not the fast repair of PLD, and that the high radiosensitivity of LEC rat cells may be associated with a deficiency in the fast repair of PLD [21]. However, whether the lack of fast repair of PLD is associated with an abnormality of DNA-PK in LEC rat cells remains unknown.

Wortmannin, a radiation sensitizer, is a fungal metabolite that was originally known as a specific inhibitor of phosphatidylinositol-3-kinase (PI3K) [1]. PI3K is fully inhibited by wortmannin at submicromolar concentrations. At high concentrations, wortmannin affects several other kinases, including DNA-PK, which belongs to the PI3K family $[28,29]$. DNA-PK has been considered to be a prime candidate for the radiosensitizing effect of wortmannin [3, 19, 25], since the inhibition of DNA-PK activity by wortmannin in vivo was found to be correlated with radiosensitization $[5,28]$ and wortmannin has been shown to inhibit DSBs rejoining [3, 19].

In the present study, we examined the effect of wortmannin on cellular survival following $\mathrm{X}$-irradiation, and we found that wortmannin enhanced the radiosensitivity of WKAH rat cells but not that of LEC rat cells.

Rat fibroblast cell lines were established and cultivated as described previously [10].

Wortmannin (Sigma Chemical Co.) was dissolved in dimethyl sulfoxide (DMSO), so that after its addition to cells the final concentration of DMSO was $<0.5 \%$. Final concentrations of DMSO in the medium were equal in control and wortmannin-treated cell populations. Small aliquots of a stock solution $(10 \mathrm{mM})$ of wortmannin in DMSO were stored at $-20^{\circ} \mathrm{C}$ and shielded from room light. For an assay of cytotoxicity of wortmannin, cells were exposed to wortmannin at $37^{\circ} \mathrm{C}$ for $24 \mathrm{hr}$ at concentrations ranging from 10 to $50 \mu \mathrm{M}$. After treatment with wortmannin, the cells were washed twice with phosphate-buffered saline (PBS), pH 7.2, and the growth 
medium was added to the cells. After the cells were incubated for 1 week, the dishes were methanol-fixed and stained with May-Grünwald and Giemsa. Colonies containing more than 50 cells were counted as survivors under a dissecting microscope.

$\mathrm{X}$-irradiation was carried out using a Hitachi MBR-1520R $\mathrm{X}$-ray generator operated at $150 \mathrm{kV}$ and $15 \mathrm{~mA}$ with a 0.5 $\mathrm{mm} \mathrm{Cu}+1.0 \mathrm{~mm} \mathrm{Al}$ filter at a dose rate of $0.95 \mathrm{~Gy} / \mathrm{min}$. Wortmannin was added to the cells at least $15 \mathrm{~min}$ before irradiation, and the cells were incubated at $37^{\circ} \mathrm{C}$. After irradiation, the cells were washed twice with PBS, and the growth medium was added. Colony assay was carried out as described above.

When WKAH rat cells were incubated in the presence of wortmannin at concentrations ranging from 10 to $30 \mu \mathrm{M}$ for $24 \mathrm{hr}$, no significant decrease in the relative surviving fraction was observed (Fig. 1). At $50 \mu \mathrm{M}$, the relative surviving fraction was arround $90 \%$ of that of untreated cells. In the case of LEC rat cells, the relative surviving fractions were slightly, but significantly, lower than those of WKAH rat cells at each concentration of wortmannin except $50 \mu \mathrm{M}$.

When WKAH rat cells were treated with wortmannin at concentrations of 20 and $30 \mu \mathrm{M}$ for $15 \mathrm{~min}$, and exposed to $\mathrm{X}$-rays, the surviving fractions decreased, compared with those of untreated cells (Fig. 2). The degree of decrease in the relative surviving fractions was dependent on the concentration of wortmannin (Fig. 1). On the contrary, no significant difference was observed between the survival curves of untreated and wortmannin-treated LEC rat cells (Fig. 2). Cytotoxicity was not observed by the treatment of both LEC and WKAH rat cells with wortmannin for short period (data not shown). Furthermore, there was no significant difference between the relative surviving fractions of wortmannin-treated LEC rat cells that had been irradiated and those that had not been irradiated (Fig. 1). These results showed that wortmannin enhanced the radiosensitivity of WKAH rat cells but not that of LEC rat cells. Wortmannin also enhanced the radiosensitivity of primary fibroblasts from WKAH rats but not that of primary LEC rat fibroblasts (data not shown).

The mechanism of the radiosensitizing effect of wortmannin is thought to be complex, since wortmannin affects several other PI3K-related kinases. The PI3K-related kinases include $\operatorname{rad} 3$ and Ers1p, which are targets of rapamycin kinases (TOR protein), ATM (mutated in ataxia telangiectasia), and ATR (ataxia telangiectasia and rad3related) [14]. Since ATM and ATR proteins seem to be associated with a cellular response to DNA damage [4, 29], the possibility that the inhibition of other proteins by wortmannin affects the radiosensitivity of WKAH rat cells can not be excluded. However, it has been reported that TOR protein is not involved in regulation of radiosensitivity, because rapamycin does not sensitize cells to radiation [28]. Inhibition of PI3K is also not likely to potentiate cellular radiosensitization since $\mathrm{PI} 3 \mathrm{~K}$ is inhibited at nanomolar concentrations of wortmannin [1], and radiation sensitization

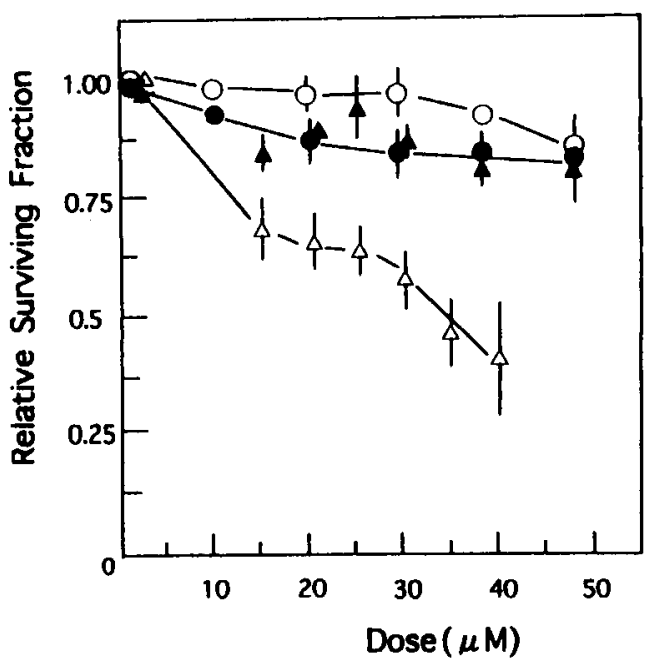

Fig. 1. Effects of wortmannin on cellular survivals. Unirradiated WKAH ( $($ ) and LEC rat (O) cells were treated with wortmannin at various concentrations for $24 \mathrm{hr}$. The WKAH rat $(\triangle)$ and LEC rat $(\boldsymbol{\Delta})$ cells were treated with various concentrations of wortmannin for at least $15 \mathrm{~min}$ before $\mathrm{X}$-irradiation at $4 \mathrm{~Gy}$. The relative surviving fractions at each concentration of wortmannin were normalized in such a way that the surviving fraction of the wortmannin-untreated cells was 1.0. Points represent the average obtained from 4-5 separate experiments ( \pm standard deviation). Standard deviations were within symbols at some points. When the cells were X-irradiated at 4-Gy, the surviving fractions of wortmannin-untreated WKAH and LEC rat cells were 0.44 and 0.18 , respectively (see Fig. 2.)

is not seen at concentrations of wortmannin lower than 2 $\mu \mathrm{M}$ [28]. Similarly, inhibition of ATR may not be a contributory factor, because wortmannin inhibits ATR at concentrations that are much higher than that required for radiation sensitization [29]. Furthermore, ATM may not be involved in the radiosensitization by wortmannin, because wortmannin enhances the radiosensitivity of AT cells [5]. Thus, DNA-PK has been considered to be a prime candidate for the radiosensitizing effect of wortmannin [3, 19, 25]. Therefore, the enhancement of radiosesitivity of WKAH rat cells is considered to be attributable to the inhibition of DNA-PK by wortmannin. On the contrary, wortmannin did not enhance the radiosensitivity of LEC rat cells. These results suggest that there may be some abnormalities in DNA-PK activity in LEC rat cells.

PLD is a form of cellular damage that is made by incubation of cells under various conditions after exposure to ionizing radiation and that is normally repaired [13]. There are at least two different forms of PLD repair, one with fast kinetics and another with slow kinetics [20, 34]. We have previously shown that the repair process of DNA DSBs induced by X-irradiation is slower in LEC rat cells 


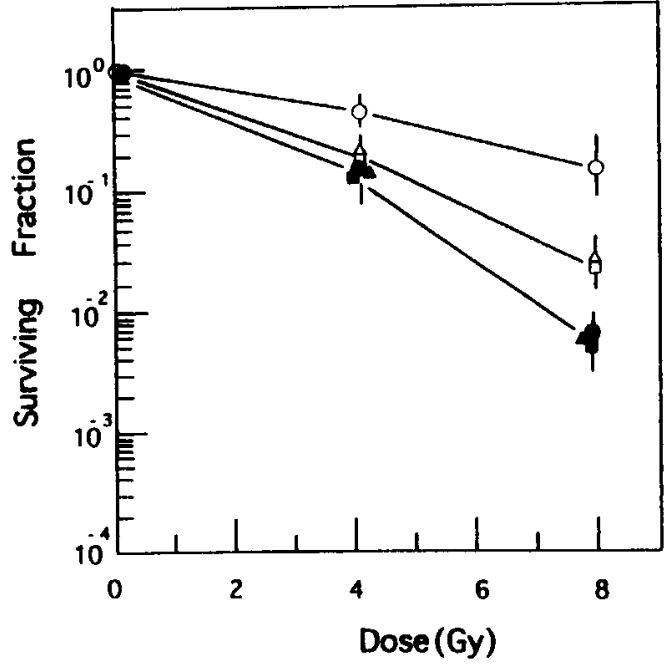

Fig. 2. Radiosensitizing effects of wortmannin on LEC and WKAH rat cells. Untreated WKAH ( $\square$ ) and LEC $(\bigcirc)$ rat cells, and wortmannin-treated WKAH $(\triangle, \square)$ and $\operatorname{LEC}(\boldsymbol{\Delta}, \boldsymbol{\square})$ rat cells at 20 $(\triangle, \boldsymbol{\Delta})$ and $30(\square, \boldsymbol{\square}) \mu \mathrm{M}$ for $15 \mathrm{~min}$ were $\mathrm{X}$ irradiated. Points represent the average obtained from 4-5 separate experiments ( \pm standard deviation). Standard deviations were within symbols at some points.

than in WKAH rat cells [9], and that the slow but not the fast repair of PLD occurred in LEC rat cells [21]. The important role of DSBs repair is suggested in the fixation of the fast form of PLD. The xrs-5 cells, a DSBs repairdeficient mutant line derived from $\mathrm{CHO}$ cells, showed a lack of fast repair of PLD [20]. Although scid mice cells show a hyperradiosensitivity, a reduced level of DSBs repair, and a deficiency of DNA- PK, the fast repair of PLD occurred in the scid mice cells [15]. Furthermore, controversial results have been reported concerning the repairability of DSBs and the occurrence of the fast repair of PLD in AT cells [26, 34]. Thus, although the relationships among fast repair of PLD, DNA-PK activity, and repair of DSBs remain unclear, the present and previous results suggest that there may be some abnormalities in DNA-PK activity in LEC rat cells, resulting in the deficiencies in repair of DSBs [9] and in fast repair of PLD [21], and a lack of the radiosensitizing effect of wortmannin. Although there is no significant difference between the total cellular activities of DNA-PK in WKAH and LEC rat cells [21], our preliminary results showed an abnormal intracellular localization of DNA-PK activity in LEC rat cells after X-irradiation. A study of the molecular characterization of DNA-PK in LEC rat cells is now in progress. The reason why unirradiated LEC rat cells showed a slightly higher sensitivity than did unirradiated WKAH rat cells to the treatment with wortmannin at concentrations from 10 to $40 \mu \mathrm{M}$ for $24 \mathrm{hr}$ remains unclear.

LEC rats could provide a useful animal model for contributing to an understanding the mechanisms of syndromes with enhanced sensitivity to ionizing radiation, and study of the sensitivity and cellular response of LEC rat cells to ionizing radiation may clarify some of the biological processes involved in the repair process of radiation-induced DNA DSBs and PLD.

ACKNOWLEDGEMENTS. This work was supported in part by a grant-in-aid from the Ministry of Education, Science, Sports and Culture of Japan, and by the Science Research Promotion Fund by the Promotion and Mutual Aid Corporation for Private Schools of Japan.

\section{REFERENCES}

1. Ancarno, A. and Wymann, M. P. 1993. Biochem. J. 296: 297-301.

2. Beamish, H. and Lavin, M. F. 1994. Int. J. Radiat. Biol. 65: 175-184.

3. Boulton, S., Kyle, S., Yalcintepe, L. and Durkacz, B. W. 1996. Carcinogenesis 17: 2285-2290.

4. Brunn, G. J., Williams, J., Sabers, C., Widerrecht, G., Lawrence, J. C. Jr. and Abraham, R.T. 1996. Embo J. 15: 5256-5267.

5. Chernikova, S. B., Wells, R. L. and Elkind, M.M. 1999. Radiat. Res. 151: 159-166.

6. German, J. 1969. Birth Defects 5: 117-130.

7. Hayashi, M., Endoh, D., Kon, Y., Yamashita, T., Hashimoto, N., Sato, F., Kasai, N. and Namioka, S. 1992. J. Vet. Med. Sci. 54: 269-273.

8. Hayashi, M., Endoh, D., Kon, Y., Yamashita, T., Sato, F., Kasai, N. and Namioka, S. 1993. J. Vet. Med. Sci. 55: 13-18.

9. Hayashi, M., Okui, T., Endoh, D., Sato, F., Kasai, N. and Namioka, S. 1994. Mutat. Res. 314: 135-142.

10. Hayashi, M., Ishimori, K., Maeda, A., Watanabe, T., Arai, S. and Okui, T. 1996. Mutat. Res. 352: 117-121.

11. Hayashi, M., Uehara, K., Kirisawa, R., Endoh, D., Arai, S. and Okui, T. 1997. J. Vet. Med. Sci. 59: 769-773.

12. Hecht, F., Koeler, R. D., Rigas, D. A., Dahnke, G. S., Case, M. P., Eisdale, V. and Miller, R. W. 1966. Lancet 2: 1193.

13. Illiakis, G. 1988. Int. J. Radiat. Biol. 53: 541-584.

14. Keith, C. T. and Schreber, S. L. 1995. Science 270: 50-51.

15. Kimura, H., Ikebuchi, M., Fushiki, M. and Komatsu, K. 1996. J. Radiat. Res. 37: 247-255.

16. Lu, X. and Lane, D. P. 1993. Cell 75: 765-778.

17. Meyn, M. S. 1995. Cancer Res. 55: 5991-6001.

18. Murray, D., Simpson, R., Rosenberg, E., Carraway, A. and Britten, R. 1994. Int. J. Radiat. Biol. 65: 419-426.

19. Okayasu, R., Suetomi, K. and Ullrich, R. L. 1998. Radiat. Res. 149: 440-445.

20. Okayasu, R., Varlotto, J. and Illiakis, G. 1993. Radiat. Res. 135: 1712-177.

21. Okui, T., Endoh, D. and Hayashi, M. 1999. Mutat. Res. 435: 81-88.

22. Okui, T., Hayashi, M., Endoh, D., Sato, F., Kasai, N., Watanabe, T. and Namioka, S. 1994. Mutat. Res. Lett. 324: 165-169.

23. Painter, R. B. and Young, B. R. 1980. Proc. Natl. Acad. Sci. U.S.A. 77: 7315-7317.

24. Paterson, M. C. and Smith, P. J. 1979. Annu. Rev. Genet. 13: 291-318.

25. Price, B. D. and Youmell, M. B. 1996. Cancer Res. 56: 246- 
250.

26. Raaphorst, G. P. and Azzam, E. I. 1985. Radiat. Res. 101: 497-507.

27. Reed, E. B., Epstein, W. L., Border, W. and Sedgwick, R. 1966. J. A. M. A. 195: 746-753.

28. Rozenzweig, K. E., Youmell, M. B., Palayoor, S. T. and Price, B. D. 1997. Clin. Cancer Res. 3: 1149-1156.

29. Sarkaria, J. N., Tibbetts, R. S., Busby, E. C., Kennedy, A. P., Hill, D. E. and Abraham, R. T. 1998. Cancer Res. 58: 43754382.

30. Sasaki, M., Yoshida, M. C., Kagamori, K., Takeichi, N., Kobayashi, H., Dempo, K. and Mori, M. 1985. Rat News Lett. 14: 4-6.
31. Smith, P. J., Anderson, C. O. and Watson, J. V. 1985. Int. J. Radiat. Biol. 47: 701-712.

32. Swift, M. R., Reitnauer, P. J., Morrell, D. and Chase, C. L. 1987. New Engl. J. Med. 316: 1289-1294.

33. Taylor, A. M. R., Metcalf, J. A. and McConville, C. 1989. Int. J. Radiat. Biol. 56: 677-684.

34. Utsumi, H. and Sasaki, M. S. 1984. Radiat. Res. 97: 407413.

35. Yoshida, M. C., Masuda, R., Sasaki, M., Takeichi, N., Kobayashi, H., Dempo, K. and Mori, M. 1987. J. Hered. 78: 361-365.

36. Zampetti-Bosseler, F. and Scott, D. 1981. Int. J. Radiat. Biol. 39: 547-558. 